\title{
Antidiarrheal and Analgesic Activities of Bouea oppositifolia (Roxb.) Adelb. in Experimental Animal Model
}

\author{
Md. Ashraful Islam ${ }^{1}$, Md. Sazzadul Bari ${ }^{1}$, Mohammad Abdullah Taher ${ }^{1}$, \\ Akhteruzzaman Chowdhury ${ }^{2}$, Md. Khalid Hossain ${ }^{1}$ and Mohammad A. Rashid ${ }^{1}$ \\ ${ }^{1}$ Department of Pharmaceutical Chemistry, Faculty of Pharmacy, University of Dhaka Dhaka-1000, Bangladesh \\ ${ }^{2}$ Government Bangla College, Mirpur 01, Dhaka, Bangladesh
}

(Received: June 20, 2020; Accepted: July 18, 2020; Published (web): July 25, 2020)

\begin{abstract}
The current study was designed to evaluate the antidiarrheal and analgesic activities of the methanol extract of Bouea oppositifolia (Roxb.) Adelb. leaves through iv vivo studies in Swiss Albino mice. Oral administration of the extract at doses of $200-$ and $400-\mathrm{mg} / \mathrm{kg}$ of body weight demonstrated statistically significant $(\mathrm{p}<0.05)$ antidiarrheal activities in castor oil-induced diarrheal mice. The extracts and standard loperamide alleviated diarrhea by margins of 31.82-, 45.45- and 68.17\%, respectively. Potential of the plant extract to effectuate analgesia was ascertained both centrally and peripherally. In tail immersion method for the determination of central analgesic activity, the plant extract at both doses enhanced pain tolerance to maximum extents of $192.76 \%$ and $221.09 \%$, respectively, compared to standard morphine (419.57\%) after 90 minutes of sample administration. Comparable levels of central analgesia were also observed for both doses of the plant extracts at 30 and 60 minutes of pharmacological intervention and the $\mathrm{p}$ value of less than 0.05 illustrated statistical significance of the activity. On a similar note, potent peripheral analgesic activities were observed for both doses of the extract as evident by 45.45 - and $54.55 \%$ inhibitions of acetic acid induced writhing responses, respectively. Compared to the standard acetylsalicylic acid characterized by $78.18 \%$ inhibition, the peripheral analgesic activity of the plant was found to be statistically significant $(p<0.05)$. The results of the study are indicative of the presence of potentially bioactive phytoconstituents with antidiarrheal and analgesic properties which might lead to newer drug candidates in future.
\end{abstract}

Key words: Bouea oppositifolia, antidiarrheal, central analgesic, peripheral analgesic.

\section{Introduction}

By virtue of their genetic ancestry and profound resilience within variant ecological systems, the plant kingdom have been illustrated with extensive mode of chemodiversity which have, in turn, established them as invaluable source of chemically complex bioactive molecules (McChesney, 1996). Furthermore, a long history of human utilization for any plant, imparts a relatively higher safety profile for the bioactive phytoconstituents available within the plant. Identification and characterization of such phytochemical entities generally commences with random biological assays of plant extracts involving in vitro simulations or experimental animal models.
These assessments, in turn, enables us to ascertain the capacities of the plant components to demonstrate discernable biochemical interactions within the biological system (Fabricant and Farnsworth, 2001). Subsequently, plant extracts with promising pharmacological activities are subjected to bioactivity guided phytochemical analysis which may ultimately lead to either novel drug molecules or candidate lead compounds for future drug developments (Sasidharan et al., 2011).

Belonging to the Anacardiaceae family, the genus Воиеа is a relatively newer and smaller genus of the angiosperms. Among only the three accepted species of the genus, Bouea oppositifolia (Roxb.) 
Adelb. (Commonly known as Plum mango or Gandaria) is endemic to southeastern part of Asia including China, Myanmar, Thailand, Indonesia, Malaysia, Laos, Cambodia, Vietnam and the Andaman Islands. The plant is most popularly known by its synonym B. microphylla. Griff. (Lim, 2012; The Plant List, 2013). The plant is also located in the Khagrachari and Chittagong districts of Bangladesh where it is locally known as Uri Aam and considered as a critically endangered species (Rahman, 2018). The plant is mainly known for its fruits and also used in the household for ornamental purposes. Both the unripe and ripe fruits were illustrated with rich contents of carbohydrates, fats, amino acids, minerals including sodium, potassium, calcium, iron and phosphorus, as well as different vitamins like retinol, thiamine, riboflavin, niacin and carotenoids (Rajan and Bhat, 2020). Phytochemical analysis with the fruits revealed the presence of at least 82 and 121 volatile constituents in unripe and ripe fruits, respectively. Mono- and sesquiterpene hydrocarbons constituted the major extent of the volatile content (32.89\% and $29.28 \%$, respectively) along with variable extent of acid, ester, alcohol, aldehyde and ketone hydrocarbons (Rajan and Bhat, 2017). Another study investigating the antioxidative potential of the plant indicated the methanol extract of unripe fruit to be capable of scavenging DPPH and $\mathrm{ABTS}^{+}$free radical to an extent of $77.69 \%$ and 99.76\%, respectively (Rajan and Bhat, 2016). Although, a number of variant medicinal properties has been associated occasionally with the plant, none of those activities were investigated scientifically. Hence, a systematic biological investigation of the plant was endeavored to evaluate potential pharmacological properties.

\section{Materials and Methods}

Preparation of the plant material: Fresh leaves of B. oppositifolia were collected from the Botanical Garden, Dhaka, Bangladesh and voucher specimen was deposited in Bangladesh National Herbarium (BNH) for future reference (Accession no. DACB56286). Properly cleaned leaves were shade-dried and ground into coarse powder. Then $650 \mathrm{~g}$ of this powder was completely immersed in $3000 \mathrm{ml}$ methanol and kept in that condition for 15 days with occasional shaking and stirring. Afterwards, the content was filtered firstly through a cotton plug and then through Whatman No. 1 filter paper. The filtrate was then concentrated with a rotary evaporator under reduced pressure at $40^{\circ} \mathrm{C}$ temperature to obtain crude methanol extract (MEBO, $73.5 \mathrm{gm}$ ).

Drugs and reagents: Methanol, Tween-80, high quality castor oil and acetic acid were procured from local market. Renowned pharmaceutical companies were contacted for acquiring different standard drugs including loperamide (Square Pharmaceuticals Ltd.), morphine (Gonoshasthaya Pharmaceuticals Ltd.), acetyl salicylic acid (Essential Drugs Company Ltd.) and normal saline (Opsonin Pharmaceuticals Ltd.). All other chemicals and solvents were of analytical grade.

Experimental animal: Swiss albino mice (25-35 g) of either sex, aged 4-5 weeks were obtained from the Department of Pharmacy, Jahangirnagar University, Bangladesh. The mice were maintained in appropriate conditions in the animal house of the State University of Bangladesh (SUB). Standard rodent feed were provided as required. Minimal physical exertion and pain induction was ensured for the experimental animals in accordance with the Federation of European Laboratory Animal Science Association's guidelines and recommendations. Sixteen Swiss albino mice were randomly divided into four groups of four animals in each group for each bioassay: positive control, negative control and two test groups receiving MEBO at doses of 200- and $400-\mathrm{mg} / \mathrm{kg}$ of body weight.

Determination of antidiarrheal activity: Antidiarrheal activity was assessed in castor oil induced diarrheal mice following the method developed by Agbor et al. (2014). Solution of $1 \%$ Tween-80 in normal saline was administered orally as the negative control at the dose of $10 \mathrm{ml} / \mathrm{kg} \mathrm{b.w}$. The positive control group was administered with loperamide at a dose of $50 \mathrm{mg} / \mathrm{kg} \mathrm{b}$.w. orally. Two test groups received the methanol extract of $B$. oppositifolia at doses of 200- and $400-\mathrm{mg} / \mathrm{kg}$ b.w. 
Individual case was allocated for each mouse with regular change of the floor lining at the end of each hour. The number of diarrheal feces excreted by the animals was recorded for 5 hours after the intervention.

Determination of central analgesic activity: Tail immersion method estimates central analgesic activity of any sample by determining the extent of delaying pain response in mice (Dewey et al., 1970). Test samples and negative control were given orally by means of a feeding needle whereas positive control morphine was administered subcutaneously at the beginning. To determine the response of mice towards painful stimulus, $1-2 \mathrm{~cm}$ of the tail of each mouse was marked and immersed in warm water kept constant at $55^{\circ} \mathrm{C}$. The time required by the mice to deflect their tails in response to that warm water was recorded as the pain response time. The first reading was discarded and the reaction time was recorded as a mean of the next three reading. A latency period of 20 seconds was defined as complete analgesia and the measurement was stopped to avoid injury to mice. The latent period of tail-flick response i.e. pain response time, was determined before the administration of drugs, followed by sample administration and a 30 minutes time period to ensure proper absorption. Then, the tail immersion times were measured at 30,60 and 90 minutes of sample administration.
Determination of peripheral analgesic activity: Peripheral pain sensation was initiated by administration of $1 \%$ acetic acid through intraperitoneal injection which, in turn, was physically manifested in the form biting or writhing of mice. Any treatment capable of producing peripheral analgesia will diminish the extent of such response (Saha and Ahmed, 2009). To start with, negative control, positive control and test sample were given orally by means of a feeding needle. A 30 minutes interval was allowed after oral administration to assure proper absorption, followed by the intraperitoneal administration of acetic acid $(0.1 \mathrm{ml} / 10 \mathrm{~g}$ b.w.). About $5 \mathrm{~min}$ after that, pain responses were recorded as number of squirms or writhing for 10 minutes.

\section{Result and Discussion}

In vivo evaluation of antidiarrheal activity in castor oil induced diarrheal mice (Table 1) demonstrated a statistically significant $(\mathrm{p}<0.01)$ $68.17 \%$ inhibition of diarrheal response as exerted by the standard drug, loperamide. Compared to this, moderate degree of statistically significant $(p<0.05)$ antidiarrheal potential was illustrated by the methanol extract of leaves of $B$. oppositifolia characterized by 31.82 and $45.45 \%$ reductions of diarrhea at doses of 200 and $400 \mathrm{mg} / \mathrm{kg}$, respectively.

Table 1. Antidiarrheal activity of methanol extract of $\boldsymbol{B}$. oppositifolia in castor oil induced diarrhea in Swiss Albino mice.

\begin{tabular}{lccc}
\hline Test groups & $\begin{array}{c}\text { Dose } \\
(\mathrm{mg} / \mathrm{kg} \text { of body weight })\end{array}$ & $\begin{array}{c}\text { Number of diarrheal feces } \\
(\text { Mean } \pm \text { SEM) }\end{array}$ & $\begin{array}{c}\text { Inhibition of diarrhea } \\
(\%)\end{array}$ \\
\hline Negative control (Normal saline) & $10 \mathrm{ml}$ & 7.33 & - \\
Positive control (Loperamide) & 50 & 2.33 & $68.17^{* *}$ \\
Methanol extract of B. oppositifolia & 200 & 5.00 & $31.79 *$ \\
& 400 & 4.00 & $45.43^{*}$ \\
\hline
\end{tabular}

All values are expressed as mean \pm SEM $(n=3)$, *indicates statistical significance of $p<0.05$ whereas $* *$ indicates statistical significance of $\mathrm{p}<0.01$.

In the tail immersion test for the determination of central analgesic activity, the methanol extract of $B$. oppositifolia at doses of 200 and $400 \mathrm{mg} / \mathrm{kg} \mathrm{b.w.,}$ enhanced pain tolerance by $192.76-$ and $221.09 \%$, respectively, after 90 minutes of sample administration, compared to that of the standard morphine (419.57\% after 90 minutes). Similar patterns of analgesic activities were also observed at 
30 and 60 minutes of sample administrations. All the responses were found to be statistically significant $(\mathrm{p}<0.05)$ indicating potent central analgesic potential for the plant (Table 2).

The peripheral analgesic activity of the methanol extract of B. oppositifolia assessed through acetic acid induced writhing test (Table 3) revealed significant activity $(\mathrm{p}<0.05)$ for the standard acetylsalicylic acid as indicated by $78.18 \%$ inhibition of writhing or pain response. Similarly, the methanol extract of the plant at doses of $200-$ and $400-\mathrm{mg} / \mathrm{kg}$ b.w. exhibited comparable analgesic activity to the standard as evident by $45.45 \%$ and $54.55 \%$ inhibition, respectively.

Table 2. Central analgesic activity of methanol extract of $B$. oppositifolia in tail immersion method.

\begin{tabular}{|c|c|c|c|c|c|c|c|}
\hline \multirow[t]{2}{*}{ Test groups } & \multirow[t]{2}{*}{$\begin{array}{c}\text { Dose } \\
(\mathrm{mg} / \mathrm{kg})\end{array}$} & \multicolumn{3}{|c|}{$\begin{array}{l}\text { Time of tail immersion } \\
(\text { Mean } \pm \text { SEM })\end{array}$} & \multicolumn{3}{|c|}{$\begin{array}{c}\text { Elongation of pain inhibition } \\
(\%)\end{array}$} \\
\hline & & $30 \mathrm{~min}$ & $60 \mathrm{~min}$ & $90 \mathrm{~min}$ & $30 \mathrm{~min}$ & $60 \mathrm{~min}$ & $90 \mathrm{~min}$ \\
\hline Negative control & $10 \mathrm{ml}$ & $2.03 \pm 0.10$ & $2.36 \pm 0.11$ & $2.62 \pm 0.33$ & - & - & - \\
\hline $\begin{array}{l}\text { Positive control } \\
\text { (Morphine) }\end{array}$ & 2 & $5.88 \pm 0.12$ & $9.72 \pm 0.09$ & $13.60 \pm 0.06$ & 189.02 & 311.14 & 419.57 \\
\hline MEBO & 200 & $3.74 \pm 0.08$ & $5.81 \pm 0.07$ & $7.68 \pm 0.26$ & 84.10 & 145.70 & 192.76 \\
\hline MEBO & 400 & $3.89 \pm .18$ & $6.57 \pm 0.09$ & $8.42 \pm 0.47$ & 91.31 & 177.86 & 221.09 \\
\hline
\end{tabular}

All values are expressed as mean $\pm \operatorname{SEM}(n=3)$, all elongation values were found to be statistically significant $(p<0.05)$.

Table 3. Peripheral analgesic activity of B. oppositifolia in acetic acid induced writhing test of Swiss Albino mice.

\begin{tabular}{lcccc}
\hline Test groups & $\begin{array}{c}\text { Dose } \\
(\mathrm{mg} / \mathrm{kg} \text { of body } \\
\text { weight) }\end{array}$ & $\begin{array}{c}\text { Average number of } \\
\text { writhing } \\
\text { (Mean } \pm \text { SEM) }\end{array}$ & $\begin{array}{c}\text { Writhing/ pain } \\
\text { response } \\
(\%)\end{array}$ & $\begin{array}{c}\text { Inhibition of pain } \\
\text { response } \\
(\%)\end{array}$ \\
\hline $\begin{array}{l}\text { Negative Control } \\
\text { (Normal saline) }\end{array}$ & $10 \mathrm{ml}$ & $18.33 \pm 0.33$ & 100 & - \\
$\begin{array}{l}\text { Positive control } \\
\text { (Acetylsalicylic acid) }\end{array}$ & 50 & $4.00 \pm 0.58$ & 21.82 & 78.18 \\
$\begin{array}{l}\text { Methanol extract of } \\
\text { B. oppositifolia }\end{array}$ & 200 & $8.33 \pm 1.33$ & 54.55 & 45.45 \\
\hline
\end{tabular}

All values are expressed as mean $\pm \operatorname{SEM}(n=3)$, all elongation values were found to be statistically significant $(p<0.05)$.

\section{Conclusion}

Our preliminary studies with the methanol extract of the leaves of $B$. oppositifolia has demonstrated prominent central and peripheral analgesia as well as antidiarrheal activity within the biological system of Swiss Albino mice. This, in turn, may provide scientific basis to warrant future indepth investigations into the plant material to identify possible bioactive constituents with aforementioned pharmacological activities.

\section{References}

Agbor, G.A., Longo, F., Makong, E.A. and Tarkang, P.A. 2014. Evaluation of the antidiarrheal and antioxidant properties of Justicia hypocrateriformis. Pharm. Biol. 52, 1128-1133

Dewey, W.L., Harris, L.S., Howes, J.F. and Nuite, J.A. 1970. The effect of various neurohumoral modulators on the activity of morphine and the narcotic antagonists in the tail-flick and phenylquinone tests. $J$. Pharmacol. Exp. Ther. 175, 435-442.

Fabricant, D.S. and Farnsworth, N.R. 2001. The value of plants used in traditional medicine for drug discovery. Environ. Health Perspect. 109, 69-75.

Lim, T.K. 2012. Bouea oppositifolia. In Edible Medicinal and Non-medicinal Plants, Springer, Dordrecht, pp. 72-74.

McChesney, J.D. 1996. Biological diversity, chemical diversity, and the search for new pharmaceuticals. In: Medicinal resources of the tropical forest: biodiversity 
and its importance to human health (Balick, M.J., Elisabetsky, E., and Laird, S.A., Eds.), Columbia University Press, New York, pp. 11-18.

Rahman, M.A. 2018. Plant diversity in Hazarikhil Wildlife Sanctuary of Chittagong and its conservation management. J. Biodivers. Conserv. Biores. Manag. 3, 43-56.

Rajan, N.S. and Bhat, R. 2016. Antioxidant compounds and antioxidant activities in unripe and ripe kundang fruits (Bouea macrophylla Griffith). Fruits. 71, 41-47.

Rajan, N.S. and Bhat, R. 2017. Volatile constituents of unripe and ripe kundang fruits (Bouea macrophylla Griffith). Int. J. Food Prop. 20, 1751-1760.

Rajan, N.S. and Bhat, R. 2020. Bioactive Compounds of Plum Mango (Bouea microphylla Griffith). In: Bioactive Compounds in Underutilized Fruits and
Nuts (Murthy, H., Niranjana, B. and Vishwas A., Eds.), Springer, Dordrecht, pp. 529-541.

Saha, A. and Ahmed, M. 2009. The analgesic and antiinflammatory activities of the extract of Albizia lebbeck in animal model. Pak. J. Pharm. Sci. 22, 7477.

Sasidharan, S., Chen, Y., Saravanan, D., Sundram, K.M. and Latha, L.Y. 2011. Extraction, isolation and characterization of bioactive compounds from plants' extracts. Afr. J. Tradit. Complement. Altern. Med. 8, 110.

The Plant List. 2013. Version 1.1. Published on the Internet; http://www.theplantlist.org/ (last accessed $14^{\text {th }}$ June, 2020). 